\title{
Planning and Implementing a Graduate Online Team-Taught Marketing Course
}

\author{
Rajasree K. NairRajamma \\ Fairfield University, rrajamma@fairfield.edu \\ Michael R. Sciandra
}

Follow this and additional works at: https://digitalcommons.fairfield.edu/business-facultypubs Copyright 2018 The Authors (Sage Publications). The authors' post-print has been archived here. Final published version is available at https://journals.sagepub.com/doi/abs/10.1177/ 0273475318786336

\section{Peer Reviewed}

\section{Repository Citation}

NairRajamma, Rajasree K. and Sciandra, Michael R., "Planning and Implementing a Graduate Online TeamTaught Marketing Course" (2018). Business Faculty Publications. 230.

https://digitalcommons.fairfield.edu/business-facultypubs/230

\section{Published Citation}

Rajamma, Rajasree K., and Michael R. Sciandra. "Planning and Implementing a Graduate Online Team-Taught Marketing Course." Journal of Marketing Education (2018). https://doi.org/10.1177/0273475318786336

This item has been accepted for inclusion in DigitalCommons@Fairfield by an authorized administrator of DigitalCommons@Fairfield. It is brought to you by DigitalCommons@Fairfield with permission from the rightsholder(s) and is protected by copyright and/or related rights. You are free to use this item in any way that is permitted by the copyright and related rights legislation that applies to your use. For other uses, you need to obtain permission from the rights-holder(s) directly, unless additional rights are indicated by a Creative Commons license in the record and/or on the work itself. For more information, please contact digitalcommons@fairfield.edu. 


\section{Planning and Implementing a Graduate Online Team-Taught Marketing Course}

Online course offerings have become a staple of higher education worldwide in the last two decades. Studies show that online course offerings have been growing at an unprecedented rate, with approximately 5.8 million students enrolled in at least one online course (Babson Survey Research Group 2016). The economic significance of online education is also considerable with some estimating the market at \$255 billion ( $\mathrm{Yu}$ and $\mathrm{Hu} 2016)$. In response to the growing demand from students and employers, several innovations have been introduced in the form of MOOCs (massive open online courses), certificate programs for skill development, and non-traditional credentials, such as digital badges and micro credentials (e.g., micro masters) to show achievement (Friedman 2017). Marketing educators have praised online learning tools and course delivery for their ability to reach new cohorts of students and enhance student learning outcomes (Granitz and Koernig 2011; Hansen 2008; Hollenbeck, Mason, and Song 2011).

Although online education has become popular among learners and administrators, it has been unpopular among faculty (Haynes 2017). Many faculty members are reluctant to teach online courses due to the perceived challenges associated with online course delivery. These limitations include increased workload and an enormous time investment in preparing and administering the course (Jones and Kelley 2003; Peltier, Schibrowsky, and Drago 2007), the need for technical knowledge and support (Lewis and Abdul-Hamid 2006; Crumpacker 2003; McGuire 2005; McKenzie 2000; Oh and Park 2009; Ryan et al, 2005; Tsai et al., 2008), lack of interpersonal relationships with the students (Mitchell et al. 2015), absence of visual cues from the students (Lee and Busch 2005), perceived disproportionality between work involved and compensation, questionable value toward tenure and promotion, (McGuire 2005), and possible 
inefficacy of online learning (Ganesh, Paswan, and Sun 2015; McKenzie et al. 2000). While previous researchers have offered several solutions, including administrative support, technological support, training and development, and motivational incentives (Crupacker 2003; Lloyd et al. 2012), the buy-in has been inconsistent among faculty members.

Considering the above, this paper highlights online team teaching as a potential solution to many concerns harbored by faculty members. In particular, we illustrate the successful implementation of an online team-taught graduate marketing course at a small northeastern university. The course discussed in this paper, Multivariate Data Analysis for Decision Making, was created by the marketing department as part of a newly instituted Marketing Analytics track housed within the business school's M.S. in Business Analytics (MSBA) program. The Marketing Analytics track in the MSBA program required students to complete three marketing analytics courses (with additional prerequisites). Two existing courses in the marketing department fulfilled two of the three course requirements for the track. The course in this paper was created as the third course in the Marketing Analytics track. The goal of this paper is to identify challenges marketing educators face while grappling with online team teaching and offer our experience as a prescriptive example for overcoming these challenges.

The remainder of this paper is organized in the following manner. First, we review relevant literature related to team teaching. Next, we outline critical stages in online team course development (contribution, preparation and coordination) and consider general challenges facing teaching teams at each stage. For each challenge, we present strategies our team used to solve the issue during the creation and execution of the course. Additionally, we offer faculty members' feedback on the development process and provide recommendations for marketing educators as they implement their own team-taught online course. Finally, we close with a discussion of 
positive educator outcomes associated with online team teaching, pinpoint areas where our team fell short, and detail implications for teaching practice.

\section{TEAM TEACHING}

Team teaching is defined as an "instructional situation where two or more teachers possessing complementary teaching skills cooperatively plan and implement the instruction for a single group of students using flexible scheduling and grouping techniques to meet the particular instructional needs of the students" (Olson Jr. 1967, p. 16). Team teaching has been implemented using different approaches, such as two faculty members teaching together, a panel of three or more faculty members from the same discipline teaching together, or a panel of interdisciplinary faculty members teaching together. Davis (1995) describes team teaching on a continuum of collaboration with joint planning but individual delivery of the content on one end and joint planning but cooperative delivery of content at the other end. Similarly, White, Henley, and Brabston (1998) identify three models of team teaching in higher education: the interactive model in which two or more professors work concurrently with a class, the rotational model in which each professor focuses on part of the course, and the participant-observer model in which professors take turns leading the instruction.

Irrespective of the approach used, team teaching has long been considered a helpful teaching method, providing meaningful learning experiences to students, especially within schools of business (Cuthbert 2005; Klein 1982; Stafford 1996). This happens as faculty with different pedagogical styles work together to help students with various learning needs (Sullivan et al., 2013). In addition, prior work has found that team teaching improves student satisfaction 
(Sullivan et al., 2013) and exposes students to broad viewpoints on topics, providing a deeper understanding of the content (Benjamin 2000; Hanusch et al., 2009; Money and Coughlan 2016). Furthermore, team teaching within business schools helps professors integrate different functional areas, such as accounting, management, and marketing, in a single course (Heinfeldt and Wolf 1998). Despite many advantages for students, several disadvantages have also been cited. Some criticisms of team-taught courses include decreased ability to learn because of differences in lecturing styles, varying quality of lecture content, and lack of cohesiveness and continuity in the course content (Hanusch et al., 2009). Students also report issues with overlapping content and conflicting messages (Money and Coughlan 2016).

Even with the advantages perceived by the students, faculty in general have been reluctant to adopt team teaching. Research has shown that team teaching requires more time commitment and effort on the part of faculty compared to teaching alone (Buckley 2000; George and Davis-Wiley 2000; Perry and Stewart 2005; Sorensen and Wittmer 1996). The lack of adequate compensation for the time and effort spent developing a team-taught course is also seen as problematic. Faculty often believe that they are rewarded only for the time they spend in class and not for the preparatory work that goes into developing the course (Mullins and Fukami 1996). Further, faculty are deterred by the fear of having other instructors in their classes or being in another faculty member's class (Davis 1995). Faculty also often view team teaching as a distraction from research and thus not in-line with general university expectations (Davis 1995). Other concerns include the psychological cost of surrendering control (Armstrong 1980, Gaytan 2010), potential conflicts from diverse personalities on the team, limited feelings of class ownership, and different teaching styles and beliefs (Young and Kram 1996). Past researchers contend that mutual trust, respect, shared responsibilities, time commitment, open-mindedness, 
flexibility, and administrative support are necessary for team teaching to succeed (Buckley 2000; Perry and Stewart 2005).

Although numerous papers explore online teaching and team teaching separately, few researchers have examined these two concepts together from the faculty's perspective. In this paper, we combine the concepts of online course delivery and team teaching to study the process underlying the successful creation of an online team-taught marketing course. Consistent with prior research on marketing course development (e.g. Athaide \& Desai 2005; DeConinck \& Steiner 1999), we examine the factors that influence the successful implementation of an online team-taught marketing course and then apply the concepts to an actual graduate level course. To do this, we identify challenges encountered during the development of the course and offer recommendations for other teams coping with online team teaching.

\section{FACTORS INFLUENCING THE SUCCESS OF ONLINE TEAM TEACHING}

\section{Contribution}

Contribution refers to inputs offered by individual team members as well as those outside the cohesive team (e.g., managers). Prior research on team composition recognizes both individual expertise and team cohesion as critical contribution attributes for team success. For example, groups whose members draw from different informational resources, including knowledge pools, experiences, backgrounds, and social structures tend to make more effective decisions (Ferrier 2001; Harrison and Klein 2007; Jackson, May, and Whitney 1995). Similarly, 
Jehn, Northcraft, and Neale (1999) found that information diversity (differences in knowledge bases and perspectives among group members) is positively associated with group performance.

Along with expertise, cohesion is a central attribute that members bring to the group and has been shown to differ from overall organizational commitment (Bishop, Scott, and Burroughs 2000). Cohesion has been conceptualized as group members' commitment to the task at hand (Goodman, Ravlin, and Schminke 1987) as well as members' attraction to the group (Evans and Jarvis 1980). In general, prior research has uncovered a positive link between group cohesion and performance (Greene 1989; Kozlowski and Bell 2013; Mullen and Cooper 1994; Smith et al. 1994). More recently, cohesion has been portioned into three dimensions: inter-personal cohesion, task cohesion, and group pride, with all these dimensions linked to group performance (Beal et al. 2003).

Finally, contributions from members outside of the group are significant for success. One major consideration is the amount of support from top managers. In particular, managerial support can assume numerous forms including guidance in goal setting, planning activities, implementing activities, and funding (Doll 1984; Thong, Yap, and Raman 1996). Given the array of areas in which managerial support can make a difference, some researchers have identified top management involvement in projects as the most critical for project success (Young and Jordan 2008).

\section{Challenge 1: How to Motivate Team Members to Participate in a Team-taught}

Online Course. Since group composition is critical for success, a major challenge is getting the right group of individuals to participate in the online team-teaching process. Amassing a group of educators with the correct knowledge, skills, and abilities, is integral to students' educational achievement. 
During an initial marketing department meeting discussing the addition of a new marketing course to the MSBA program, many faculty members immediately expressed their reluctance to participate. Two of the faculty members were already teaching graduate courses, two were pre-tenure and needed time to work on research, and one was the chair of the department. Additionally, the fairly stringent tenure and promotion requirements at the university led some to question the value in teaching a graduate marketing analytics course. The concern stemmed from the perception that analytical courses typically resulted in lower student evaluations, required more time to prepare and deliver, and lacked student interest.

After consulting with the dean of the school of business, the chair proposed the idea of team teaching the course as a solution to some of the faculty concerns. It was expected that team teaching (1) would not constrain faculty resources as each faculty member will have to do only a fraction of the work, and (2) would minimize the time commitment required, thereby allowing time to work on research and service activities. In addition, it was proposed to offer this course online and during the summer term. The proposal to offer the course online was based on the rationale that a majority of the faculty members travel to international locations during summer. Thus, flexibility was a prime consideration for the faculty. In addition, a summer course has the additional benefit that would alleviate the severe resource constraint that would be imposed on the department (being a small department with only eight full time faculty members), had the course been offered during the regular semester.

In subsequent meetings, the faculty again raised several concerns regarding a team-taught online course such as (1) lack of familiarity with online teaching and course delivery (2) the degree of technical support that the university would provide, and (3) how a teaching team would be compensated. 
In response to faculty members concerns' with a team-taught course, the department chair provided a series of solutions. First, to mollify concerns regarding time investment, lack of experience with online course development, and the university's degree of technical support of such a course, the chair met with members of the University's Information Technology Services (ITS) department and the university's Center for Academic Excellence (CAE). The CAE offers expert guidance and assistance to professors in the areas of teaching and learning. Members of both departments signaled an openness to work with the marketing department to develop the course. This support included offering training sessions to faculty members on online course composition, educating faculty members on university tools for creating digital lecture materials, and consulting on technical issues that might be encountered during the preparation of the course.

Second, to address faculty members' concerns with compensation, the chair met with the dean of the school of business to identify a practical solution. During a normal summer term, the university pays faculty a set dollar amount per summer course. The dean offered to split this figure equally among faculty members participating in the team-taught course. Furthermore, during this meeting, additional compensation opportunities were discussed to help incentivize faculty participation. Given the novelty of a team-taught online course, the dean recommended applying for a school of business teaching innovation grant as well as exploring additional teaching awards offered at the university level ${ }^{1}$.

The chair presented all the information addressing the concerns of the faculty members during a department meeting. The distribution of the course preparation duties across the

\footnotetext{
${ }^{1}$ The teaching team applied for and received a teaching innovation grant from the school of business in the amount of $\$ 5000$ which was split among the team members. Additionally, at the university level, the team received a Presidential Award for Pedagogical Innovation. This award provided financial support for the educational mission of the course and allowed the team to present the course at the university's annual Faculty Development $\&$ Evaluation Committee conference.
} 
teaching team, the summer online course offering, and the additional summer course compensation, were all positives the faculty took away from the discussion. With the support of the ITS and CAE departments, all members of the faculty believed that other small concerns with the course could be easily solved. Thus, five faculty members (including the department chair) volunteered to become part of the teaching team.

The final teaching team brought a set of diverse and extensive backgrounds to the planning and execution of the course. All five members of the team had PhDs in marketing as well as degrees in fields outside of marketing (two general business MBAs, one MBA in management information systems, and two B.S. degrees in engineering). Additionally, all members of the team had real-world work experience in areas as diverse as brand management, product development, and tax accounting. All members had also received extensive training in statistical analysis during their Ph.D. programs and were active researchers in marketing. Finally, team members contributed a diverse cultural background with two members from the U.S., one from India, one from Iran, and one from Romania.

In interviews conducted one week after the development and execution of the online team-taught course, team members highlighted some of the strategies offered to encourage participation as critical to the ultimate success of the course. This sentiment is evident in the following responses from team members:

The amount of external support was amazing. The people in the Information Technology Services (ITS) department were very influential in the success of the course. They did a very good job in supporting the instructors as well as ensuring a smooth course delivery. The financial support provided by the university was an important and encouraging factor 
for me personally. The teaching grant, provided by the school of business and the dean, was also another motivating factor.

Outside support, especially from the university’s technology group (ITS), was tremendous. The fact that they were willing to work with us throughout the process of developing the course (as opposed to simply stepping in at the end to help launch the course) was paramount to the course's success. I would encourage anyone who is planning to construct an online course to bring in the technology folks early and often. For this team-taught course, having the technology folks in the room from the beginning made the entire experience quite positive.

Recommendation 1: Identify departments and support staff with technical and/or pedagogical knowledge in online team teaching. Engaging these departments early in the course development process can help mitigate educators' concerns and encourage participation. Think broadly about forms of compensation available to the teaching team. Consider awards or grants offered at the department, school, university, or external level.

\section{Preparation and Coordination}

Based on the life cycle model of team management (Hertel et al., 2005), preparation refers to tasks and decisions for laying the project's foundation and setting goals for the task

ahead. These activities are critical as successful preparation has been tied to the effectiveness of teams (Hoegl and Parboteeah, 2003; Mathieu and Rapp 2009; Maynard et al., 2012). Additionally, coordination is defined as "the use of strategies and behavior patterns aimed at 
integrating and aligning the actions, knowledge, and objectives of interdependent members, with a view to attaining common goals" (Rico et al. 2008, p. 163). Like preparation, team coordination plays a significant role in the effective functioning of the team and is essential for team success (Rathnam et al., 1995.) Traditional views on coordination identify two types of coordination: planning coordination and communication coordination. Teams use coordination via planning, also known as administration coordination or impersonal coordination, to manage routine and predictable aspects of work such as deadlines, plans, and schedules (Rico et al. 2008). On the other hand, coordination via communication involves formal and informal exchanges of information among team members with the goal of integrating the respective contributions (Kraut and Streeter 1985; Rico et al., 2008). While one individual can effectively handle the administration process, it is important for more than one team member to participate in coordination via communication (Rico et al. 2008). Consistent with this idea, prior research has found that decentralized decision structures where team members share a role in joint decision making are positively associated with the quality of team outcomes (Hoegl and Parboteeah 2006).

In the context of online team teaching, preparation encompasses preliminary course decisions including (1) selecting team leaders, (2) agreeing on the goals of the team and creating a general course outline, and (3) setting expectations for the faculty team. Once course preparation begins, coordination becomes key as a few highly-educated individuals with different working styles, teaching styles, and opinions will have to be stewarded toward a common goal. See Table 1 for a detailed list of preparation and coordination activities the teaching team undertook in the development of the course. 
- Insert Table 1 about here -

\section{Challenge 2: How to Set Goals, Establish Expectations, and Monitor Team Progress.}

For our course, in-depth planning began during the spring 2016 semester (approximately oneand-a-half years prior to the course launch). During initial meetings, the team members (1) identified a team leader, (2) pinpointed important course topics, (3) formulated course learning objectives, (3) and set course development deadlines, through collegial discussions.

One of the most critical facets of our course preparation and planning was a project champion. A project champion is a person who makes "a decisive contribution to the innovation by actively and enthusiastically promoting its progress through the critical [organizational] stages" (Achilladelis, Jervis, and Robertson 1971, p. 14). Previous researchers have indicated that champions often take ownership of the project, are passionate about the project and promote the idea through "formal and informal networks" to ensure the success of the project (Schon 1963). Organizational research has long recognized the role of project champions in building team confidence, developing project support and resources, improving the efficiency of the team, and thus, the successful implementation of the project (Pinto and Slevin 1989; Markham 1998).

One member of the teaching team, in our case, the department chair herself, assumed the role of project champion (later chosen as the team leader) in the nascent stages of the course planning and development process. This individual initially presented the course idea to the dean, persuaded faulty members of the course's benefits, worked with representatives from the CAE and ITS departments, and ensured the course planning process ran smoothly. Additionally, this individual organized meeting among team members and meetings with outside stakeholders such as the dean and ITS support staff. 
Reflecting upon the course development strategies in an interview a week upon course completion, faculty members stressed the importance of identifying a project champion and setting course expectations early in the planning and coordination process. These sentiments are detailed in the following quotes from team members:

The teaching team was thoroughly prepared. The work started well in advance of the course, and all team members had multiple opportunities to not only be part of constructing the course but also provide insights and suggestions for modifications. It was very important that the team identified a "lead" who could organize and orchestrate launching the course. It made the entire process smooth and efficient. I believe that effective team organization and leadership was crucial to the course's success.

Along with selecting a leader, the team identified critical course topics and learning objectives during early preparation meetings. As part of this process, the project champion/ team leader conducted extensive research on the learning objectives and content of similar courses offered by other institutions. She prepared and presented a report summarizing the findings and common topics across syllabi. The teaching team then identified five multivariate techniques critical to marketing (i.e., factor analysis, cluster analysis, multidimensional scaling, correspondence analysis, and conjoint analysis) for inclusion in the course. Based on collegial discussions, each member of the teaching team agreed to focus on a different technique (called a "module") that he/she was on an expert on, and was responsible for preparing the educational 
content for the course. Each module was further divided into smaller "units" to create a more manageable learning experience for students.

Each team member's expertise in a particular content area allowed them to determine important course information critical for students to understand as well as present the material in a manner that maximized student learning. Furthermore, two professors brought expertise in online teaching, thereby providing helpful best practices for the current course. This focus on expertise is emphasized in the following quotes captured during our interviews with two of the team members:

I think all the instructors had the skill, knowledge, and ability to teach all the modules of this course because we have been trained extensively in this topic (multivariate research techniques). I used to teach a fully-online course and that experience helped me a lot. I tried to share my experiences with the team as much as possible.

In my role [as associate dean and director of graduate business programs], I have input and insight into students' experiences and perspectives with online learning at the graduate level. Thus, I believe that my most useful contribution was that I could spot if something was occurring in the construction of this course that would lead to negative issues with students. For example, students who take online classes often complain about the lack of connection with the faculty member, or else the lack of accessibility to the faculty member. As a result, our team made it quite explicit that each member would be available at specified times. This action, though minor, does a lot to mollify students' anxiety for online learning. 
Along with assigning course modules to team members, the team agreed upon the deadlines for each activity related to the course. The team realized earlier in the process that when left alone, faculty are likely to prioritize imminent tasks (e.g., current courses, research, advising, or service) over the preparation of the focal course. To motivate faculty to stay on track, the team leader/project champion requested that each faculty member share with the team what he or she had done and articulate any issues or suggestions they wished to share. Therefore, progress of the team objectives and deadlines were constantly monitored during meetings and any issues, best practices, or potential problems were discussed. This sort of friendly peer pressure kept most faculty on track. The target dates were well ahead of the course start date, thus allowing the team ample time to accommodate minor defaults by team members.

After completing of the course, one team member underscored the importance of team accountability and reinforced an example where this strategy kept the teaching team focused. In particular, the team member noted that:

In the beginning, I was concerned about " $\mathrm{A}$ " (a team member) finishing the tasks on time. A was postponing everything! But since we had to share what we had done with regard to our module during each meeting, this sort of put pressure on everyone to do their best. It was friendly self-policing. So, I guess, after the first couple of slip-ups, this person realized that he/she was letting the team down. After that everything went very smoothly. 
Additionally, members of the teaching team discussed the team's success in setting goals and coordinating efforts. This can be seen in the following testaments from the faculty:

The team did a wonderful job setting guidelines and deadlines that everybody agreed on. If there were any small disagreements, they were collegially resolved in a timely manner. Furthermore, the team did an excellent job coordinating with Information Technology Services (ITS) to ensure a smooth delivery of the course via Blackboard and communicating with students.

I thought the team was very well coordinated. All instructors discussed and agreed on the content structure, as well as the delivery format [of the course]. The expected interactions with students were also well coordinated (i.e., different roles assigned to different people), which significantly reduced the amount of unnecessary or redundant communications.

Recommendation 2: Identify a project champion early in the course preparation and planning process. Keep team members accountable to the process by periodically requiring each individual to provide progress reports, share questions, and articulate concerns with the teaching team.

Challenge 3: How to Achieve Uniformity among the Course. Since the course was taught by five faculty members with very different personalities, different teaching styles, and various teaching philosophies, obtaining uniformity throughout the course was a challenge. The 
team wanted the course to feel like one cohesive whole rather than an amalgam of disparate lessons. While team members recognized the need for uniformity, achieving this goal was much more difficult than anticipated. Several members had differing ideas on how to standardize content presentation while others trivialized this goal.

After several rounds of discussion on the issue, the team eventually agreed on a number of strategies to inject consistency into the course presentation. All course material used the same visual presentation including fonts, color schemes, and format. Even details, such as opening sentences within each module and self-introduction of the faculty members, were discussed and agreed upon. Similarly, the team standardized the structure and length of all course modules. Each module consisted of three to four units which were no more than 15 minutes in length. After finishing each course unit, students completed a short five question multiple choice quiz to assess learning. Finally, at the end of each module, students completed a module final exam created by the module instructor to test their knowledge and ability to apply the material. To further tie modules together, each faculty member applied the same teaching case and examples. It was decided that the team leader would be the point person communicating with the students with regard to all general topics such as handling the course introduction announcements, quiz and exam reminders, as well as posting the final grades for the course. Faculty teaching each module would respond only to module-related questions, communicate module-related information, and post module final exam grades. This had the added advantage that the time commitment required from each team member would only be a week instead of the five weeks during which the course was offered.

Once again, the team's focus on course standardization is reflected in the following sentiment expressed by one of the faculty members during an interview with one of the authors: 
The team worked very closely from the very beginning, so that we approached our individual sections in a similar way- thus from the student's perspective. I believe that students felt that the course was consistent and not simply patched together via different lectures.

Recommendation 3: Standardize course content and presentation among the teaching team to achieve uniformity in course delivery.

Challenge 4: How to Collect Student Feedback to Improve the Course. During course preparation, the teaching team faced another major challenge: designing procedures to collect student feedback. This was a critical consideration as all members of the teaching team required evidence of teaching excellence for the tenure and promotion process $^{2}$. Given the team-taught structure of the course, we questioned the best way to collect this information. In particular, the team was facing three major considerations: (1) how to collect individualized feedback for all five instructors, (2) how to minimize student fatigue with evaluations, and (3) how to keep this information anonymous, private, and confidential.

Traditional courses at the university use the IDEA Student Ratings of Instruction instrument (IDEA 2018) coupled with a supplemental offline questionnaire to collect qualitative feedback from students. The teaching team felt that the IDEA evaluation instrument would be too long for students to complete multiple times. Additionally, the teaching team believed that students might become confused completing the IDEA survey instrument multiple times as it is

\footnotetext{
${ }^{2}$ Specifically, two members of the team were assistant professors looking to achieve tenure and advance to the rank of associate professor while three members of the team were associate professors hoping to advance to full professor in the near future.
} 
best suited for collecting feedback on an entire course rather than individual parts of a class (i.e., the individual modules of the course). Therefore, the team decided to adapt the university's traditional qualitative questionnaire for the five course modules. After each module, students were asked to complete a series of five open-ended questions collecting feedback on the content of the module as well as on the individual instructor teaching the module. A unique evaluation link was included at the end of each module using Qualtrics survey software. The team considered administering the module evaluations using the quiz functionality in the Blackboard course page; however, this idea was abandoned for two reasons. First, it would be difficult to ensure true anonymity for student feedback as instructors could potentially see which students have completed the evaluation. Secondly, the results of each module evaluation would be accessible by all members of the teaching team, thereby infringing upon the confidential nature of each faulty member's reviews. Using a unique Qualtrics survey which was only accessible to the module instructor mitigated both of these potential issues.

Recommendation 4: Consider collecting course evaluations for each instructor involved in the course as individualized feedback can be used to support teaching effectiveness during the tenure and promotion process. Identify an evaluation system that preserves the privacy of both students and faculty members.

Challenge 5: How to Ensure the Online Course is Ready for Students. The reliance on technology as well as the wide range of individuals working on the development of this course created an additional challenge for the educational team. Mainly, faculty members questioned whether the course would function as intended and therefore considered strategies to 
flush out latent issues in the course delivery. While each member of the teaching team evaluated and tested the educational content housed within each teaching module, some members of the team worried that familiarity would lead the team to overlook potential problems. Given the online nature of the course, the likelihood of problems arising in different areas, such as course consistency, clarity of delivery, and simplicity of instructions, are quite high. Therefore, the team decided to undergo a period of beta-testing for the course. The use of beta-testing to uncover potential problems before product introduction is a well-recognized practice in the software industry. To ensure that the course met the teaching and presentation goals set by the team, we identified two graduate business students to fully complete the modules and provide feedback. The students testing the course, identified issues with the course presentation, technology, assignments, and exams, and provided advice to the teaching team on how to improve each module. This helped the team detect and troubleshoot issues before the course was launched in the summer.

Recommendation 5: Identify a group of individuals to test all aspects of the course (instructions, lecture materials, videos, assignments, and exams) before the course is rolled out to students. This instructional beta-test can uncover issues before the course goes live.

\section{Course Implementation: The Final Product}

Analytical courses are not often offered online because of the perceived difficulty caused by lack of face-to-face contact with students. Due to student demand and curriculum developments, the marketing department ran the course during one of the summer semesters (July 1st - August 8th) with thirteen students enrolled in the course. The reason for the small 
class size stems from the fact that MSBA program was a newly-launched program and the business school graduate program was relatively small. Students came from different backgrounds, but one of the prerequisites of the course was that they had to complete a graduate level introductory marketing course as well as a master's level marketing research course. Therefore, students in the class were familiar with the SPSS statistical program which was used in this course.

The course consisted of five one-week modules, each delving into a particular multivariate technique critical to marketing (i.e., factor analysis, cluster analysis, multidimensional scaling, correspondence analysis, and conjoint analysis). Each module was further divided into smaller units which housed part of the module. Units consisted of a video presentation of the lesson with a voice-over by the faculty member teaching that portion of the course. The video lecture was strictly limited by all faculty members to $10-15$ minutes duration for each unit. This was based on the finding that for maximizing student learning, video lectures should be limited to 15-minute intervals (Berg et al. 2014). Each module consisted of three to four educational units (i.e., video lectures) and one demonstration unit applying the multivariate method to actual data using SPSS statistical software (See Appendix A for ascreen shot of how the course video components appeared to students). All lecture videos were created using Zoom Video Communication software and were hosted on the university server. These unit videos were then embedded and playable within the Blackboard educational system. Hence, Blackboard was the focal educational platform used by students during the course. To comply with disability accommodation guidelines and overcome issues associated with individual differences in faculty speech, students received a detailed verbatim transcript of each video lecture. 
As a team, we wanted to assure the students that we were available to support their learning, despite the absence of face-to-face contact in the course. Toward this end, the team leader was highlighted as the "go-to person" for general course-related issues, while individual faculty members were the primary contact for the individual modules. An introductory course video provided students with clear guidelines and was accompanied by a document answering course FAQs and listing important course contacts. At the beginning of the course, the project champion sent a welcome email to students detailing the course structure. In addition, a reminder about the opening and closing of each module was emailed by the project champion. Module instructors contacted the students mid-week, asking students about their progress and informing them that they were available to answer any questions that may arise while completing the lectures.

To test the students' understanding of the material covered in each unit, we incorporated a short quiz at the end of every unit that was automatically graded by the Blackboard educational system. Students were allowed to attempt each unit quiz twice with their grade being the better of the two scores. Each unit was designed so that the next unit in the module would only open up after the student submitted the quiz for the prior unit. At the end of each module, students completed a module final exam which tested their understanding of the concepts covered in that module (including using SPSS to run and interpret results). Three of the five modules used a case that involved marketing decision making. For Module 1, Module 2 and Module 3 exams, students used the case data to perform factor analysis, cluster analysis, and multi-dimensional scaling to answer questions related to marketing decision making related to the case. Module 4 and Module 5 exams used different datasets where students performed correspondence analysis, 
and conjoint analysis respectively and responded to questions related to marketing decisions. Figure 1 provides the course structure.

- Insert Figure 1 about here -

Student learning was self-paced with every module lasting for one week. During the week, students were encouraged to contact the faculty member teaching the module if they had questions pertaining to the course, the team leader if they had general questions about the course, and ITS if they had questions or issues associated with the course technology. The teaching team primarily received questions about the module final exams; however, three faculty members received clarification questions from students, and the team leader received an access-related issue from one student (which was then resolved by ITS). At the end of each week, students submitted their module final exam. The Blackboard system was programmed to release the subsequent module only after students submitted the prior module final exam. The faculty graded module exams and entered grades into Blackboard within 72 hours of the exam as per the university policy.

At the end of each module, students received a unique survey link to collect feedback on the instructor, critical aspects of the module that contributed to student learning, and areas for future improvement. These evaluations provided individual guidance on each module and were intended to help the team identify trouble spots in the course content and delivery. Additionally, upon completion of the course, students completed a final survey capturing feedback on reactions to the course as a cohesive whole. Therefore, student feedback was received six times throughout the duration of the course. 


\section{POSITIVE EDUCATOR OUTCOMES AND AREAS FOR IMPROVEMENT}

From an educator's perspective, the online team-taught course offered many positive outcomes. First, the course expanded the teaching portfolio of each team member and introduced each professor to new technologies that can be incorporated in future classes (both offline and

online). This sentiment is demonstrated in the following reflection from one of the professors:

One of the most beneficial aspects of this course was the ability to teach new content to a group of students with whom I don't usually interact. Normally, my course schedule is relatively consistent from semester to semester. This course allowed me the opportunity to focus on different material and expand the nature of my teaching. In addition, this course exposed me to many new teaching programs and enhanced my understanding of how to use existing teaching technologies. There are a number of tools we used in the development of this course that will be useful in my offline teaching (e.g., using video lectures to work on "flipping" my classroom).

A second positive outcome highlighted by the teaching team was the flexibility of an online team-taught course. For example, professors reported the sharing of resources and the ability of the class to allow for multiple teaching orientations. This is exhibited in the following assessments: 
One of the best aspects of this course is that it was not as labor-intensive as a course taught by a single instructor.

I liked the modular structure of the course. This gives the instructors the flexibility to implement their own teaching style while ensuring the consistency across the modules. At the end of the day, I personally chose a career in academia because I like the freedom of applying my own teaching strategies and tools without being forced to adopt someone else's methods/tools. In addition, teaching a summer class in an online format is ideal for tenure-track faculty because of the flexibility it provides time-wise.

A third positive result was the opportunity for more detailed student interactions and engagement. Indeed, prior research recognizes that student engagement and interactions in online environments are achievable despite being in a different form when compared to on-campus instruction (Robinson and Hullinger 2008). Team members described these interactions and engagements as an aspect of the course that was both surprising and unique. For example, the following quotations underscore this sentiment from the teaching team:

In some respects, the completely online course provided the opportunity to interact more closely with students than if one was in a physical classroom. Although I did not have many instances of outreach during the course, in the case of one particular student who struggled with a statistical technique, I was able to quickly and adequately address his concerns because we were in constant communication via email. Hence, we had to be 
clear and concise, which I believe enabled him to more easily understand where he was making a mistake.

Having different faculty focus on different content worked quite well. When dealing with empirical issues and [statistical] software, I think that having different "voices" teaching the various techniques actually made it more interesting and engaging for the students.

The overall positive feedback solicited at the end of the course also reinforces the positive learning outcomes from students' perspectives as well. The following student comments received via open-ended questions included in the end of the course survey illustrate this perspective:

I really enjoyed this class. All the modules were fun, interesting, and useful. I like learning specific applicable skills and how to apply them, so this class was great.

To be very honest, this was the best online course I studied. The explanation of all the modules exceeded expectations. I think other online courses should follow a similar pattern with recordings.

Despite the positive outcomes identified by the teaching team, there are a few areas of improvement for future iterations of this course. This is unsurprising as prior research recognizes the need for continuous improvement while teaching in online environments (Hirschheim 2005). 
The first area of improvement is defining better protocols for technology issues. While the educational team identified contact persons to troubleshoot minor technology issues and no major issues developed during the course delivery, there was limited contingency planning surrounding the potential for major technological failures. This concern is emphasized in the following responses from faculty members:

While the course provides ample flexibility to complete each of the modules, it is difficult to provide students with extra time and opportunities if technical issues were to arise during the week.

A more complete plan on how we will deal with serious technological issues can help ensure a smoother process in the future. By creating a contingency plan for major technological issues we will be in a position to proactively manage major technology failures and ease student anxieties.

Therefore, future courses should include a contingency plan to address technological failures as advocated in prior research (Swift et al 1997; Milheim 2001). Strategies may consist of hosting unit videos on backup servers, creating alternate content for each module, and/or assigning backup instructors to assume module instruction in the case of an emergency for a member of the teaching team.

Along with improved planning surrounding technology failure, another area for improvement lies in soliciting student feedback on the course. As previously discussed, students completed teacher evaluations for each member of the educational team, directly after the 
completion of each module. While this approach allowed for individualized feedback, it appears that students may have felt overwhelmed by the number of assessments or failed to recognize the importance of evaluating each team member. The fatigue felt by the students was demonstrated by the fact that the response rate was approximately $70 \%$ for the first two modules and gradually decreased to smaller percentages (approximately 30\%) by the end of the course. The team members articulated this as a major concern as student evaluations are an important component of tenure and promotion decisions. To avoid this problem, the student evaluation survey may be linked to the final exam for the module. The system could be programmed such that the student evaluations must be completed before the module's final exam is released to students. Further, instructors could also consider including a few scaled questions or a combination of scaled and open ended questions, instead of only open ended questions which typically elicit lower response rates (Denscombe 2009).

Another problem encountered during the course delivery was related to the self-paced learning aspect of the modules. Each module was released to students on Sunday morning at 12:00 am and the final exam was due a week later on Saturday evening by 11:59 pm. Therefore, students had an entire week available to them to review the video lectures, work on the quizzes, and submit the final exam. However, the majority of students waited until Thursday or even Friday to start working on the modules (probably because many worked full time). Normally, this would not be a problem. However, if an issue were to arise, such as with technology, it meant that support had to be available at the last minute causing stress to all involved - students, faculty, and technology support personnel. Further, there were requests to change the deadline for the submission of the exam. In a much larger class, changing submission deadlines due to technology problems would likely create havoc with course management. Hence, we recommend 
that teaching teams communicate at the start of the course that deadlines will not change and prompt students to start working on course modules at the beginning of the week.

\section{CONCLUSION}

Team teaching in an online environment is a highly complex endeavor that requires a significant amount of planning, coordination, and support from many individuals. Detailed planning, extensive coordination, and the ability to procure support from administrators and ITS were critical to the successful implementation of the course. In addition, having a project champion was critical to the success of the course. While online courses are popular among students and university administrators, many faculty have been reluctant to venture into online pedagogy. Therefore, in this paper we detailed the development and implementation of an online team-taught graduate marketing course. We focused on faculty team members' experiences and feedback on the execution of the course as an instructional example to alleviate concerns with online teaching. While the course described in this paper had a small class size, we believe that the prescriptive insights offered can be applied to classes of all sizes. Moreover, although the team size in our course was large with five faculty members, the suggestions given in this paper are equally relevant to smaller teams.

In prior work on online teaching, faculty raised many criticisms including increased workload or time investment, a need for technical knowledge and support, the nature of the interactions with students, a lack of visual aids in the teaching environment, perceived gaps between work investments and requisite compensation, and the murkiness of such classes in the tenure and promotion process. We believe our experiences in implementing a team-taught online 
course offers a gateway into online teaching environments and addresses some of the major concerns raised by faculty members.

Increased Time Investment. While online teaching requires a significant amount of upfront work prior to the execution of a course, approaching this hurdle with a team of educators makes the upfront investment less daunting. Also, a number of the faculty noted that working with a team significantly reduced the amount of time invested when compared to an individuallyprepared course. In addition, in the case of the course described in this paper, even though the course duration was five weeks, each team member had to invest only a week in teaching the course.

Need for Technical Knowledge and Support. The online nature of a course clearly necessitates new technical knowledge and tools. By approaching an online course with a team, we believe this actually improves the likelihood that faculty will be successful in utilizing these tools. The presence of a team creates a learning community around such technologies and provides a support system for professors. In addition to working with the teaching team, our experiences highlight the importance of including information technology staff early in the course preparation.

Student Interactions. Professors often voice concerns about student interactions and engagement with online teaching. While online interactions are different, that does not mean that they have to be nonexistent. Faculty members found that the online environment actually enhanced the closeness of student interactions, especially with those struggling with a particular portion of the course.

Lack of Visual Aids. Online "classrooms" look quite different from the traditional learning space we are all familiar with. However, there are many tools that allow professors to 
integrate some of the most engaging visual content (i.e., slides, pictures, videos) in online educational materials. We used Zoom and Blackboard software to display our slides and statistical analyses during each module of the course.

Compensation Issues. Due to increased time spent preparing online courses, professors do not necessarily see compensation increase at a fair rate. While this is an issue that is highly idiosyncratic to each college or university, our experiences offer a number of insights to mitigate this concern. In particular, our team presented the online team-taught nature of this course as an important pedagogical advancement at our university ${ }^{3}$. This allowed us to secure additional funds via university and school awards focusing on new advancements in teaching. Thus, the faculty developing the course received compensation for the upfront investment of time and effort. Further, a major time commitment occurs only at the developmental stage of the course. Once the course is prepared and launched, the same material can be used with minor improvements in subsequent semesters. This provides the faculty teaching the course with additional time for research and service and possibly additional revenue ${ }^{4}$ (depending on university policies) in the upcoming semesters. Hence, faculty developing the course should consider the long-term value of the effort expended rather than focusing on the short-term challenges.

Questionable Value for Promotion. Another major concern voiced by faculty is the questionable value of online courses in the tenure and promotion process. Again, while a highly idiosyncratic consideration depending on university requirements, the teaching team identified positive outcomes that might aid in the promotion process. Team members noted that this course

\footnotetext{
${ }^{3}$ Due to a shift in the strategic focus of the university, the faculty was encouraged to develop more online courses, especially during the summer.

${ }^{4}$ As our university policies allow faculty to earn extra pay for summer courses, offering the course during summer provided the team with the added benefit of a revenue stream for a foreseeable future.
} 
allowed them to teach new material, thus broadening their teaching portfolios, a critical aspect often assessed during promotion decisions (Babin, Shaffer, and Tomas, 2002). Additionally, faculty members recognized that the team approach created efficiencies that enabled team members to focus on other critical academic endeavors (e.g., research and service).

\section{Limitations}

Although the authors' experience with the course was positive, additional challenges may arise for other teaching groups implementing a similar course. As pointed out earlier, the support provided by those outside the department is critical to the success of any venture within a university. If a teaching team's goals coincide with that of the university, it may be easier to obtain the support from these outside groups. Furthermore, incentives and grants are variable from university to university. In the absence of adequate incentives, faculty may refuse to participate despite other positive environmental factors.

Additionally, the class size for the course described in this paper was small, allowing a lot of flexibility and control over course decisions. Although the suggestions in this paper are not class size dependent, some of our recommendations might need to be tested to prove efficiency in larger class settings. The implementation and applicability of a team-taught online course is also dependent on the policies of the university regarding online-courses, team teaching, compensation, and courseload requirements of participating faculty. Since our course ran during the summer term, courseload considerations were not a factor. However, we caution those considering implementing a similar course during traditional semesters and recommend investigating how their college or university weighs team-taught courses for courseload 
requirements. Finally, the focal course described in this paper was offered at the graduate level. Therefore, the results may differ when implemented at the undergraduate level as the dedication and motivation of graduate students may be quite different from undergraduate students. 


\section{REFERENCES}

Achilladelis, B., Jervis P., \& Robertson A. (1971). A study of success and failure in industrial innovation, Sussex, England: University of Sussex Press.

Armstrong, F. H. (1980). Faculty Development through Interdisciplinarity. The Journal of General Education, 32(1), 52-63.

Athaide, G. A. \& Desai, H. B. (2005). Design and Implementation of an Interdisciplinary Marketing/Management Course on Technology and Innovation Management, Journal of Marketing Education, 27(3), 239-249.

Babin, L. A., Shaffer, T. R., \& Tomas, A. M. (2002). Teaching Portfolios: Uses and Development, Journal of Marketing Education, 24(1), 35-42.

Babson Research Group (2016), “Online Report Card: Tracking Online Education in the United States," Retrieved from https://onlinelearningconsortium.org/read/online-report-cardtracking-online-education-united-states-2015/

Beal, D. J., Cohen, R. R., Burke, M. J., \& McLendon, C. L. (2003). Cohesion and Performance In Groups: A Meta-Analytic Clarification Of Construct Relations. Journal of Applied Psychology, 88(6), 989-1004.

Benjamine, J. (2000). The Scholarship of Teaching in Teams: What Does it Look Like in Practice? Higher Education Research and Development, 19, 191-204.

Berg, R., Brand,A., Grant,J., Kirk,J., \& Zimmermann, T. (2014). Leveraging Recorded MiniLectures to Increase Student Learning, Online Classroom, 14(2), 5-8.

Bishop, J.W., Scott, K.D., \& Burroughs, S.M. (2000). Support, Commitment, and Employee Outcomes in a Team Environment, Journal of Management, 26(6), 1113-1132.

Buckley, F. (2000) Team Teaching: What, Why and How? Thousand Oaks, CA: Sage

Crumpacker, N. (2001). Faculty Pedagogical Approach, Skill, And Motivation in Today's Distance Education Milieu, Online Journal of Distance Learning Administration, 4(4).

Cutbert, P.F. (2005). The Student Learning Process: Learning Styles or Learning Approaches? Teaching in Higher Education, 10(2), 235-249.

Davis, J.R. (1995). Interdisciplinary Courses and Team Teaching: New Arrangements for Learning, Phoenix. AZ: American Council on Education and Oryx Press.

DeConinck, J. \& Steiner, T. (1999). Developing an Integrated Finance and Marketing MBA Core Course, Journal of Marketing Education, 21(1), 44-50. 
Denscombe, M. (2009). "Item Non- Response Rates: A Comparison of Online and Paper Questionnaires," International Journal of Social Research Methodology, 12 (4), 281-291.

Doll, W.J. (1985). Avenues for Top Management Involvement in Successful MIS Development, MIS Quarterly, 9(1), 17-35.

Evans, N. J., \& Jarvis, P.A. (1980). Group Cohesion: A Review and Reevaluation. Small Group Behavior, 11(4), 359-370.

Ferrier, W.J. (2001). Navigating the Competitive Landscape: The Drivers and Consequences of Competitive Aggressiveness, Academy of Management Journal, 44(4), 858-877.

Friedman, J. (2017). “5 Education trends to watch in 2017," U.S. News and World Report, Jan 05.

Ganesh, G., Paswan, A., \& Sun, Q. (2015). Are Face-To-Face Classes More Effective than Online Classes? An Empirical Examination, Marketing Education Review, 25(2), 67-81.

Gaytan, J. (2010). Instructional Strategies to Accommodate a Team-Teaching Approach, Business Communication Quarterly, March, 82-87.

George, M.A..\& Davis-Wiley, P. (2000). Team Teaching a Graduate Course, College Teaching, 48(2), 75-84.

Goodman, P. S., Ravlin, E.C., \& Schminke, M. (1987). Understanding Groups In Organizations, In L. L. Cummings \& B. M. Staw (Eds.), Research in Organizational Behavior (vol. 9, pp. 121-173). Greenwich, CT: JAI Press.

Granitz, N. \& Koernig, S. K. (2011). Web 2.0 and Marketing Education: Explanations and Experiential Applications, Journal of Marketing Education, 33(1), 57-72.

Greene, C.N. (1989). Cohesion and Productivity in Work Groups, Small Group Behavior, 20(1), 70-86.

Hansen, D. E. (2008). Knowledge Transfer in Online Learning Environments, Journal of Marketing Education, 30(2), 93-105.

Hanusch, F., Obijiofor, L., \& Volcic, Z. (2009). Theoretical and Practical Issues in Team Teaching a Large Undergraduate Class, International Journal of Teaching and Learning in Higher Education, 21(1), 66-74.

Harrison, D.A. and Klein, K.J. (2007). What's The Difference? Diversity Constructs as Separation, Variety, or Disparity in Organizations, Academy of Management Review, 32(4), 1199-1228. 
Haynes, C. (2017). "Breaking through the Stigma of Online Education," Retrieved from https://www.insidehighered.com/digital-learning/views/2017/05/24/breaking-stigmaonline-education

Heinfeldt, J., \& Wolf, F. (1998). Re-Engineering the Business Curriculum: A Stakeholder Paradigm, Journal of Education for Business, 73, 198-201.

Hertel, G., Geister, S., \& Konradt, U. (2005). Managing Virtual Teams: A Review of Current Empirical Research, Human Resource Management Review, 15(1), 69-95.

Hirschheim, R. (2005). The Internet-Based Education Bandwagon: Look before You Leap, Communications of the ACM, 48 (7), 97-101.

Hoegl, M., \& Parboteeah, P.K. (2003). Goal Setting and Team Performance in Innovative Projects: On the Moderating Role of Teamwork Quality, Small Group Research, 34, 319.

Hoegl, M., \& Parboteeah, P.K. (2006). Autonomy and Teamwork in Innovative Projects, Human Resource Management, 51 (1), 67-79.

Hollenbeck, C. R., Mason, C. H., \& Song, J. H. (2011). Enhancing Student Learning in Marketing Courses: An Exploration of Fundamental Principles for Website Platforms, Journal of Marketing Education, 33(2), 171-182.

Idea (2018). Solutions to Improve Teaching and Learning. Retrieved from https://www.ideaedu.org/Services.

Jackson, S. E., May, K.E., \& Whitney, K. (1995). Understanding the Dynamics of Diversity in Decision-Making Teams, In Richard A. Guzzo and Eduardo Salas, eds., Team Effectiveness and Decision Making in Organizations (pp. 204-261), San Francisco, CA: Jossey-Bass.

Jehn, K. A., Northcraft, G.B., \& Neale. M.A. (1999). Why Differences Make A Difference: A Field Study of Diversity, Conflict and Performance in Workgroups, Administrative Science Quarterly, 44(4), 741-763.

Jones, K. O., \& Kelley, C. A. (2003). Teaching Marketing Via the Internet: Lessons Learned and Challenges to Be Met, Marketing Education Review, 13(1), 81-89.

Klein, G. D. (1982). Team-teaching Within Schools of Business: Increasing the Chance for Success, Journal of Marketing Education, 4(3), 54-64.

Kozlowski, S.W.J, \& Bell, B.S. (2013). Work Groups and Teams in Organizations: Review Update, In Handbook of Psychology: Vol. 12. Industrial and organizational psychology, second edition (pp. 412-69), ed. N. Schmitt \& S. Highhouse, London, England: Wiley. 
Kraut, R.E., \& Streeter, L.A. (1995). Coordination in Software Development, Communications of the ACM, 38(3), 69-82.

Lee, J.A., \& Busch, P.E. (2005). Factors Related to Instructors' Willingness to Participate in Distance Education," The Journal of Educational Research, 99(2), 109-115.

Lewis, C. C., \& Abdul-Hamid, H. (2006). Implementing Effective Online Teaching Practices: Voices Of Exemplary Faculty. Innovative Higher Education, 31(2), 83-98.

Lloyd, S.A., Byrne, M.M., \& McCoy, T.S. (2012). Faculty-Perceived Barriers of Online Education, Journal of Online Learning and Teaching, 8(1), 1-12.

Maguire, L. L. (2005). Literature Review: Faculty Participation in Online Distance Education: Barriers and Motivators, Online Journal of Distance Learning Administration, 8(1). Retrieved from http://www.westga.edu/ distance/ojdla/spring81/maguire81.htm

Markham, S.K. (1998). A Longitudinal Examination of How Champions Influence Others to Support their Projects, Journal of Product Innovation Management, 15 (6), 490-504.

Mathieu, J. E., \& Rapp, T.L. (2009). Laying the Foundation for Successful Team Performance Trajectories: The Role of Team Charters and Performance Strategies, Journal of Applied Psychology, 94(1), 90-103.

Maynard, T.M., Mathieu, J.E., Rapp, T.L., \& Gilson, L.L. (2012). Something(s) Old and Something(s) New: Modeling Drivers of Global Virtual Team Effectiveness, Journal of Organizational Behavior, 33, 342-365.

McKenzie, B.K., Mims,N., Bennett, E., \& Waugh, M. (2000). Needs, Concerns and Practices of Online Instructor, Online Journal of Distant Education Administration, 3 (3), Retrieved from: http://www.westga.edu/ distance/ojdla/fall33/mckenzie33.html

Milheim, William (2001), "Faculty and Administrative Strategies for the Effective Implementation of Distance Education," British Journal of Educational Technology, 32 (5), 535-542.

Mitchell, L., Parlamis, J.D., \& Claiborne, S.A. (2015). Overcoming Faculty Avoidance of Online Education, Journal of Management Education, 39(3), 350-371.

Mullen, B., \& Copper, C. (1994). The Relation between Group Cohesiveness and Performance: An Integration, Psychological Bulletin, 115(2), 210-227.

Mullins, J.W., \& Fukami, C.V. (1996). Stage 4: The Raging Debates, Journal of Management Education, 20 (4), 446-61. 
Money, A., \& Coughlan, J. (2016). Team-Taught Versus Individually Taught Undergraduate Education: A Qualitative Study of Student Experiences and Preferences, Higher Education, 72, 797-811.

Oh, E., \& Park, S. (2009). How are Universities Involved in Blended Instruction? Journal of Educational Technology \& Society, 12(3), 327-42.

Olson Jr., C. (1967). Why Teaching Teams Fail, Peabody Journal of Education, 45 (1), 15-20.

Peltier, J. W., Schibrowsky, J. A., \& Drago, W. (2007). The Interdependence of the Factors Influencing the Perceived Quality of the Online Learning Experience: A Causal Model, Journal of Marketing Education, 29(2), 140-153.

Perry, B., \& Stewart, T. (2005). Insights into Effective Partnership in Interdisciplinary Team Teaching, System: An International Journal of Educational Technology and Applied Linguistics, 33(4), 563-73.

Pinto, J.K., \& Slevin D.P. (1989). The Project Champion: The Key to Implementation Success, Project Management Journal, 20(4), 15-20.

Rathnam, S., Mahajan,V., Whinston, A.B. (1995). Facilitating Coordination in Customer Support Teams: A Framework and Its Implications for Information Technology, Management Science, 41(12), 1900-21.

Rico, R., Sanchez-Manzanares, M., Gil, F., \& Gibson, C. (2008). Team Implicit Coordination Processes: A Team Knowledge-Based Approach, Academy of Management Review, 33(1), 163-184.

Robinson, C.C., \& Hullinger, H. (2008). New Benchmarks in Higher Education: Student Engagement in Online Learning, Journal of Education for Business, 84 (2), 101-109.

Ryan, M., Hodson-Carilton,K., \& Ali, N.S.(2005). A Model for Faculty Teaching Online: Confirmation of a Dimensional Matrix, Journal of Nursing Education, 44(8), 357-365.

Schon, D.A. (1963). Champions for radical new inventions. Harvard Business Review, 41 (March-April), 77-86

Smith, K.G., Smith, K.A., Olian, J.D., Sims Jr, H.P., O'Bannon, D.P., \& Scully, J.A. (1994). Top Management Team Demography and Process: The Role of Social Integration and Communication, Administrative Science Quarterly, 39(3) 412-438.

Sorensen, J. E., \& Wittmer, D.P. (1996). Stage 2: Designing Team-taught Transdisciplinary Courses - Where Do We Begin? Journal of Management Education, 20(4), 422-434. 
Stafford, T. F. (1996). A Tale of Two Cities: Team Teaching in Action, Journal of Marketing Education, 18(3), 3-13.

Sullivan, D., Colburn, M., Fox, D.F. (2013). The Influence of Learning Styles on Student Perception and Satisfaction in a Highly Collaborative Team-taught Course, American Journal of Business Education, 6(4), 429-438.

Swift, Cathy Owens, Jerry W. Wilson, and Jane P. Wayland (1997), "Interactive Distance Education in Business: Is the New Technology Right for You?" Journal of Education for Business, 73 (2), 85-89.

Thong, J.Y.L, Yap, C-S., \& Raman, K. S. (1996). Top Management Support, External Expertise and Information Systems Implementation in Small Businesses, Information Systems Research, 7(2), 248-267.

Tsai, I., Kim, B., Pei-Ju, L., Goggins, S. P., Kumalasari, C., \& Laffey, J. M. (2008). Building a Model Explaining the Social Nature of Online Learning. Journal of Educational Technology \& Society, 11(3), 198-215.

White, C.S., Henley, J.A., \& Brabston, M.E. (1998). To Team Teach or Not to Team Teach That is the Question: A Faculty Perspective, Marketing Education Review, 8(3), 13-23.

Young, M.B., \& Kram, K.E. (1996). Repairing the Disconnects in Faculty Teaching Teams, Journal of Management Education, 20(4), 500-515.

Young, R., \& Jordan, E. (2008). Top Management Support: Mantra or Necessity? International Journal of Project Management, 26(7), 713-725.

Yu, J., \& Hu, Z. (2016). Is Online Learning the Future of Education? World Economic Forum, Retrieved from https://www.weforum.org/agenda/2016/09/is-online-learning-the-futureof-education/ 
TABLE 1

COURSE PREPARATION AND COORDINATION ACTIVITIES

\begin{tabular}{|c|c|c|}
\hline Date & Members & Purpose \\
\hline October 20,2015 & $\begin{array}{l}\text { One member of the team met with } \\
\text { the dean of the school of business. }\end{array}$ & $\begin{array}{l}\text { The meeting was to propose the possibility of } \\
\text { offering a team-taught course at the graduate } \\
\text { level. }\end{array}$ \\
\hline January 29, 2016 & $\begin{array}{l}\text { One member of the team met with } \\
\text { the dean of the school of business. }\end{array}$ & $\begin{array}{l}\text { The purpose of the meeting was to inform the } \\
\text { dean about the Department's need to offer a } \\
\text { multivariate course, and express faculty's } \\
\text { interest in offering this as an online team- } \\
\text { taught course. The dean verbally approved } \\
\text { the proposal. }\end{array}$ \\
\hline February 23, 2016 & $\begin{array}{l}\text { Informal discussion among the } \\
\text { members of the department. }\end{array}$ & $\begin{array}{l}\text { Following the department meeting, an } \\
\text { information discussion was held among the } \\
\text { faculty to identify volunteers for teaching the } \\
\text { proposed online course. }\end{array}$ \\
\hline March 11, 2016 & $\begin{array}{l}\text { All members of the teaching team } \\
\text { interacted over email to discuss the } \\
\text { team-taught course. }\end{array}$ & $\begin{array}{l}\text { During these email exchanges, members of } \\
\text { the teaching team worked on generating } \\
\text { general course content, learning goals, and an } \\
\text { assurance of learning plan. Based on the } \\
\text { discussions, a rough syllabus is developed } \\
\text { eventually and distributed for the team's } \\
\text { approval. } \\
\text { The proposal for Summer teaching innovation } \\
\text { grant offered by the business school is also } \\
\text { discussed and approved during these email } \\
\text { exchanges }\end{array}$ \\
\hline April 01, 2016 & $\begin{array}{l}\text { One member of the team met with } \\
\text { members of the University's } \\
\text { Information Technology } \\
\text { Department (ITS). }\end{array}$ & $\begin{array}{l}\text { During the meeting the team member laid out } \\
\text { her vision regarding structure and } \\
\text { presentation of the course and explored ITS's } \\
\text { capabilities to help the team develop the } \\
\text { envisioned structure }\end{array}$ \\
\hline May 6, 2016 & $\begin{array}{l}\text { All members of the teaching team } \\
\text { met to discuss preliminary } \\
\text { information on the course. }\end{array}$ & $\begin{array}{l}\text { Members of the teaching team met to discuss } \\
\text { best practices in online and team teaching. A } \\
\text { general outline of the course was developed } \\
\text { and each member selected a content module } \\
\text { to focus on. Furthermore, during this meeting } \\
\text { team members discussed course objectives, } \\
\text { set preliminary deadlines for the course } \\
\text { creation, and discussed possible text books } \\
\text { for the course. }\end{array}$ \\
\hline May 9, 2016 & $\begin{array}{l}\text { Two members of the teaching team } \\
\text { met with representatives from a } \\
\text { multivariate statistical software } \\
\text { company. }\end{array}$ & $\begin{array}{l}\text { The teaching team members met virtually } \\
\text { with representatives to learn more about the } \\
\text { company's software and the possibility of } \\
\text { deploying the software in the course. }\end{array}$ \\
\hline May 9, 2016 & All members of the teaching team & During this meeting, members of the teaching \\
\hline
\end{tabular}




\begin{tabular}{|c|c|c|}
\hline & $\begin{array}{l}\text { met with representatives from the } \\
\text { University's Information } \\
\text { Technology Services (ITS). }\end{array}$ & $\begin{array}{l}\text { team explained the course and its general } \\
\text { objectives to members of the ITS department. } \\
\text { This meeting helped flush out details of the } \\
\text { course and pinpoint specific technologies that } \\
\text { might be used in the creation and delivery of } \\
\text { the educational content. }\end{array}$ \\
\hline May 11, 2016 & $\begin{array}{l}\text { One member of the team met with } \\
\text { the dean. }\end{array}$ & $\begin{array}{l}\text { The purpose of the meeting was to update the } \\
\text { dean on the progress of the course } \\
\text { preparation. }\end{array}$ \\
\hline June 29,2016 & $\begin{array}{l}\text { Team applies for the President's } \\
\text { Innovations in Teaching award }\end{array}$ & $\begin{array}{l}\text { The team was selected for this award from } \\
\text { among several applicants \& was given the } \\
\text { award in September } 2016 .\end{array}$ \\
\hline November 16, 2016 & $\begin{array}{l}\text { All members of the teaching team } \\
\text { met with two representatives from } \\
\text { the ITS department. }\end{array}$ & $\begin{array}{l}\text { The representatives from the ITS department } \\
\text { demonstrated how to use video and screen } \\
\text { capturing software to be used in the } \\
\text { development of course lectures. This meeting } \\
\text { allowed team members to familiarize } \\
\text { themselves with the software and to ask } \\
\text { additional questions. }\end{array}$ \\
\hline February 18, 2017 & $\begin{array}{l}\text { All members of the teaching team } \\
\text { met to refine the syllabus for the } \\
\text { course. }\end{array}$ & $\begin{array}{l}\text { During this meeting and subsequent } \\
\text { interactions via email, members of the } \\
\text { teaching team worked on refining and editing } \\
\text { a draft syllabus for the course. }\end{array}$ \\
\hline March 8, 2017 & $\begin{array}{l}\text { All members of the teaching team } \\
\text { were present to discuss important } \\
\text { issues related to the course. }\end{array}$ & $\begin{array}{l}\text { During this meeting the team focused on how } \\
\text { unit quizzes and module exams should be } \\
\text { graded, selected a case example to be used in } \\
\text { all of the content modules, and made changes } \\
\text { to the course syllabus. Additionally, the team } \\
\text { selected appropriate templates to standardize } \\
\text { all documents throughout the course (i.e. } \\
\text { slides, lecture transcripts, and final exams). }\end{array}$ \\
\hline April 1-May 1, 2017 & Course dry run & $\begin{array}{l}\text { Two graduate students were asked to go } \\
\text { through the modules as 'mock students' and } \\
\text { give feedback to the team and the faculty } \\
\text { teaching the module. This allowed minor } \\
\text { issues to be rectified before the course was } \\
\text { launched. }\end{array}$ \\
\hline May 3, 2017 & $\begin{array}{l}\text { Three of the five team members } \\
\text { presented the course at the } \\
\text { University's Faculty Development } \\
\text { \& Evaluation Committee conference }\end{array}$ & $\begin{array}{l}\text { This presentation allowed the team to } \\
\text { received feedback and input from a larger } \\
\text { group of educators outside of the business } \\
\text { school. }\end{array}$ \\
\hline May 16, 2017 & $\begin{array}{l}\text { All teaching team members met } \\
\text { with representatives from the ITS } \\
\text { department }\end{array}$ & $\begin{array}{l}\text { The team discussed issues related to the } \\
\text { online presentation of the course. Topic } \\
\text { included standardizing the presentation of } \\
\text { material, finalizing unit examinations, and } \\
\text { setting up adaptive release for all course } \\
\text { modules. }\end{array}$ \\
\hline
\end{tabular}


FIGURE 1

\section{COURSE STRUCTURE}

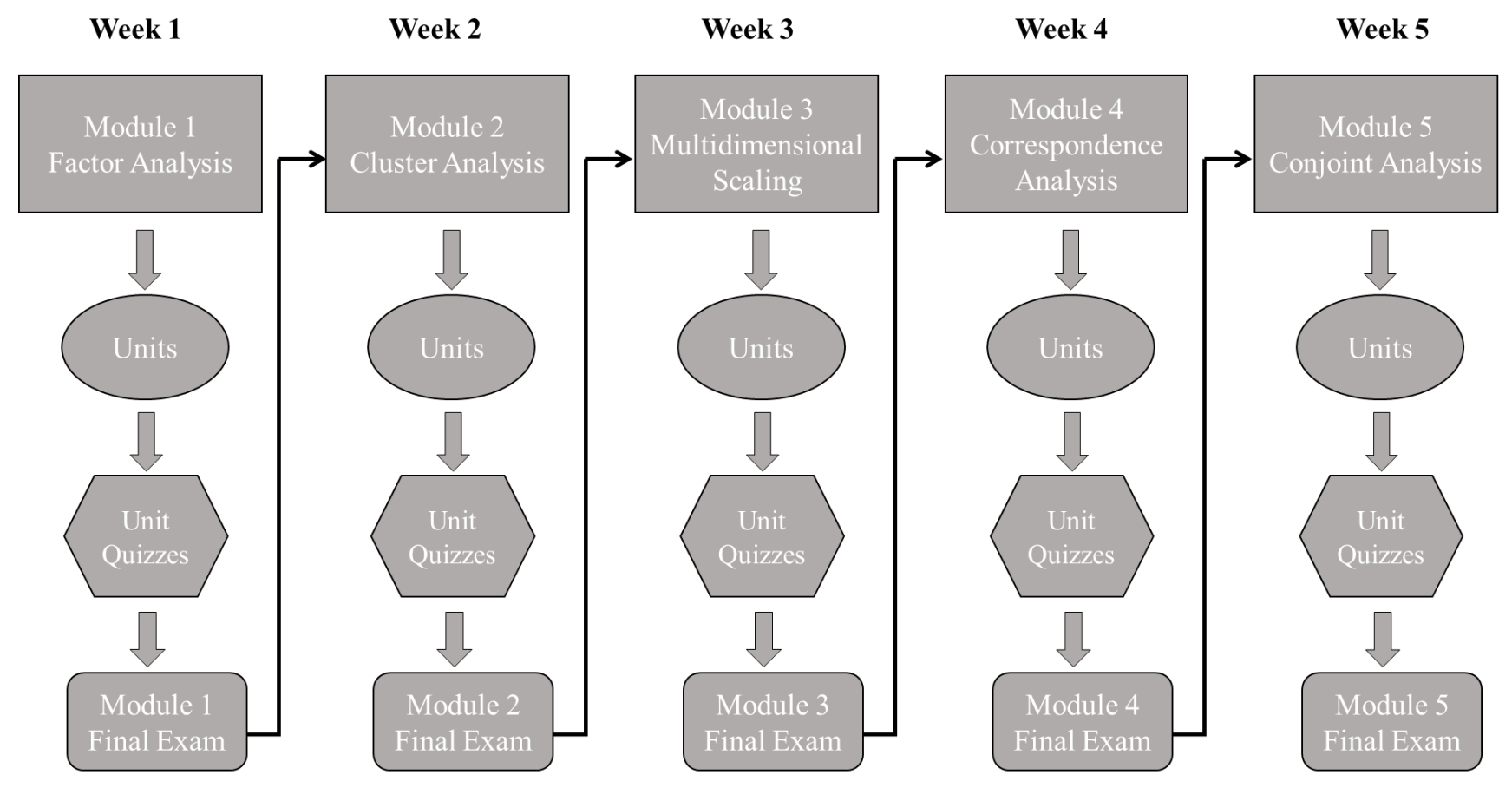




\begin{abstract}
APPENDIX A
SCREEN SHOTS OF UNIT LECTURE VIDEO AND SPSS LECTURE

VIDEO
\end{abstract}

\title{
What's Wrong With Asking About Importance?
}

- When buying a bike, how important is the...

- Weight?

- Comfort?

- Speed?

- Price?

- Brand?

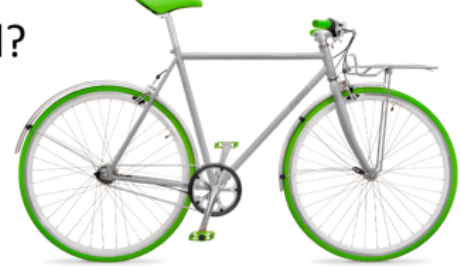

Attribute Importance

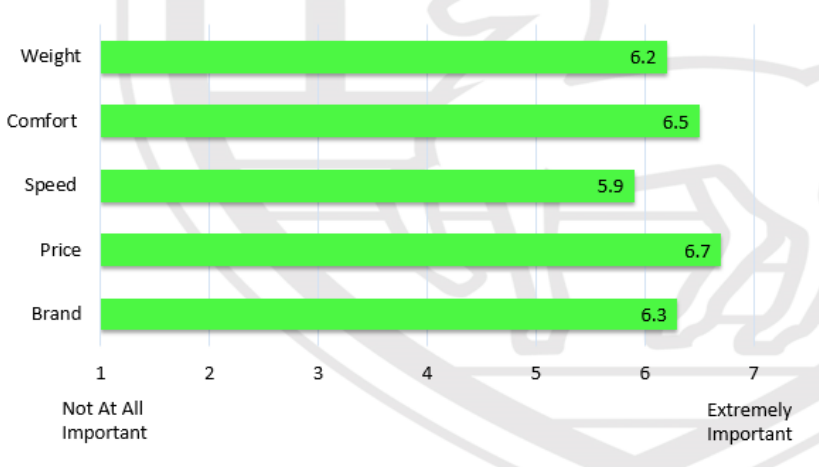


Ele Edi View Data Iransform Enalyze Graphs untifities Extensions Window Help

刍回的圆匹

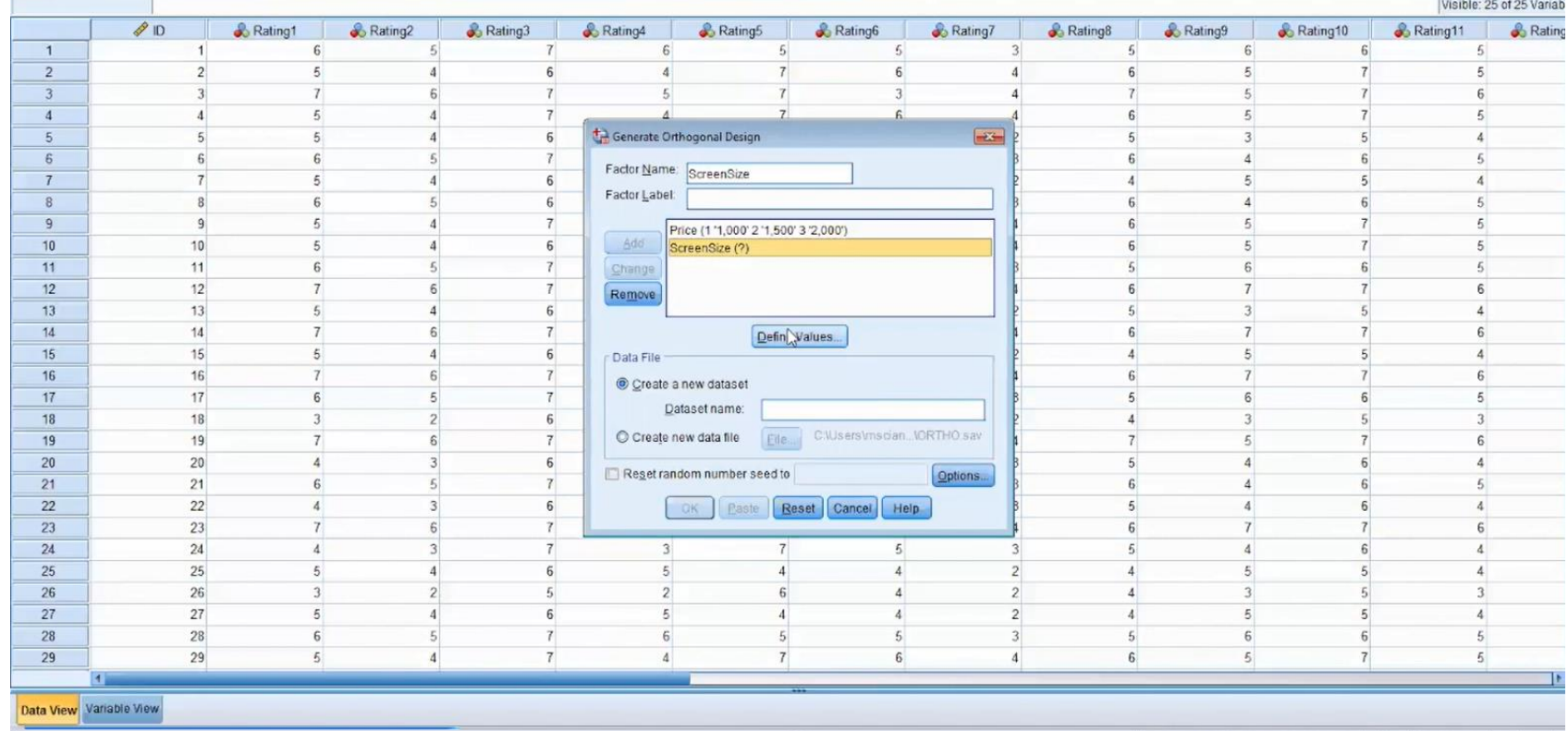

